\title{
RELATIONSHIP BETWEEN CLINICAL EFFECTIVENESS AND PHARMACOECONOMIC COST IN PATIENTS WITH DIABETES MELLITUS
}

\author{
${ }^{1}$ Ilavská, A. - ${ }^{2}$ Cviková, V. - ${ }^{3}$ Šimúnová, E. - ${ }^{4}$ Hroncová, D. - ${ }^{5}$ Foltán, V. \\ ${ }^{1}$ Centre for Diabetes and Metabolic Diseases, Medispektrum s.r.o, Bratislava, \\ Slovak Republic \\ ${ }^{2}$ Faculty of Philosophy, Comenius University, Bratislava, Slovak Republic \\ ${ }^{3}$ AT\&T Slovakia, Bratislava, Slovak Republic \\ ${ }^{4}$ Mediforum, GSK Non-commercial Centre of Education, Bratislava, Slovak Republic \\ ${ }^{5}$ Department of Organisation and Management in Pharmacy, Faculty of Pharmacy, \\ Comenius University, Bratislava, Slovak Republic
}

\begin{abstract}
Therapeutic practices and effectiveness have a crucial impact on healthcare system costs in diabetes mellitus treatment with significant economic implications. Encompassing up to $15 \%$ of the healthcare budget in the Slovak Republic, diabetes mellitus imposes a huge economic burden on the Slovak healthcare system.

The paper analyzes the treatment needs and medication costs for diabetes between 2004 and 2010 in the Slovak Republic. Both insulin and oral antidiabetic therapy are available for all patients depending on the severity of the disease. The costs analysis clearly indicates a great impact of diabetology on healthcare. The results of this work have confirmed that diabetes mellitus is a costly disease, and the costs are expected to grow further. With respect to the increasing demand and limited resources, there is a growing need for additional economic analyses. To achieve control of costs in the decision making processes in the Slovak Republic, the role of pharmacoeconomics should be strengthened.
\end{abstract}

Key words: diabetes mellitus - treatment - costs - pharmacoeconomic evaluation - quality of life

\section{INTRODUCTION}

Diabetes mellitus can be considered as a model of a chronic lifelong disease with progressive complications. Pharmacoeconomics offers a complex view on diabetes in the long-term horizon. It evaluates the economic impact of both preventive and therapeutic practices in the long run. The opportunity of influencing both long-term and short-term strategies and the selection of the most effective therapeutic regime is of 
crucial importance, aiming at maximization of benefits of financial resources expended $[1,2]$. The modeling can analyze the relevant and specific costs for a particular country. The whole spectrum of outcomes can be explored in modeling relevant for diverse groups of stakeholders in the healthcare system, such as the payers, managing authorities, and clinical workers [3, 4]. Pharmacoeconomic modeling used in the study constitutes an extrapolation and imputation for the assessment of the effectiveness of antidiabetics used in healthcare according to the parameters useful for the analysis of effectiveness of resource utilization.

The objective of this paper is to present a complex overview of the issues of diabetes mellitus in terms of diagnostics, therapy, and quality of life. This manuscript aims:

- to evaluate direct costs for DM treatment in the Slovak Republic,

- to explore the quality of life and overall life satisfaction in diabetic patients and to identify the incidence of depressive symptoms and anxiousness in the population of diabetic patients,

- to evaluate the possibility of influencing the costs of treatment of diabetes mellitus as well as of treatment of DM complications by modeling.

\section{MATERIAL AND METHODOLOGY}

The pharmacoeconomic evaluation of the effectiveness of invested resources includes prevention and treatment of this chronic metabolic disease as well as the influence of both acute and chronic complications of diabetes mellitus on quality of life. In addition modeling as a tool of pharmacoeconomic decision making and its scoring/judging is applied $[5,6]$.

\section{Data pooling and analysis}

To apply a complex view, the following methods were used:

\section{- evaluation of direct costs for DM treatment,}

Baseline for evaluation of direct costs is represented by epidemiological data, accessed and processed for our needs with the agreement of the National Centre for Health Information (NCFHI). Comparative analysis that takes into account the structure as well as the type of the treatment was used.

\section{- evaluation of quality of life in DM patients}

For the four concepts currently used relating to the quality of life research and personal mental well-being we used the WHO model (WHOQOL) [7]. The multidimensional concept of quality of life includes personal well-being as an emotional component, satisfaction as a cognitive component, social functioning as a performance component, and life purpose as a spiritual component [8]. With respect to the significance of this parameter, the quality of life is one of the most critical pharmacoeconomic indicators and it has a significant impact on pharmacoeconomic modeling. The following methods were used in the surveillance $[9,10]$ :

1. Initial questionnaire - to detect baseline socio-demographic data, duration of a disease, type of diabetes, diabetes complications etc. 
2. Life satisfaction questionnaire - to detect the overall life satisfaction of an individual and differentiation of satisfaction into ten areas,

3. Depression questionnaire - Beck depression index (BDI) - to detect depressive symptoms,

4. Spielberger anxiety and anxiousness questionnaire (State-Trait Anxiety inventory - STAI - section X-2 for anxiousness) - to detect anxiousness as a specific feature.

- pharmacoeconomic modeling of treatment costs for DM and DM complications was used

The methodology is based on the Markov model combined with Monte Carlo simulation, appropriate for expressing repetitious situations and chronic disease progression. The model used in our analysis was the CORE model (Center for Outcomes Research Diabetes Model) - the most often used model in diabetology. It is a validated interactive computer model used in simulations of long-term health outcomes and economic consequences of interventions in DM1 or DM2 using clinical parameters such as HbA1c, systolic blood pressure, lipids, serum cholesterol, and body mass index (BMI).

The modeling in the Core model predicts DM2 progression in the long-term horizon, as the outcomes recorded include the most relevant published epidemiological and clinical data such as the United Kingdom Prospective Diabetes Study (UKPDS) [11]. The Core model comprises 15 sub-models for simulation of the most common DM complications, such as angina pectoris, coronary heart disease, cataract, congestive heart disease, leg ulcers and amputations, hypoglycemia, ketoacidosis, lactacidosis, edema of the macula, myocardial infarction, nephropathy, peripheral vascular disorder, retinopathy, stroke, and non-specific mortality. Parallel occurrence of these sub-models allows for the development of concomitant complications in hypothetical subjects. The cohorts may be defined by demographic characteristics: age, sex, initial risk factors, and pre-existing complications. This model was validated by 66 published studies, including external validation (3rd rank) in DM2 simulations [12, 13].

To detect the statistical significance of mean differences of overall life satisfaction relating to gender, type of diabetes, as well as depressive and non-depressive respondents, a t-test for equality of means of two independent selections was used.

\section{Pharmacoeconomic model of DM treatment and complications}

In order to compare the effectiveness, the results of the meta-analysis of the indirect comparison between two antidiabetic medications detemir and glargine were used.

The cost analysis was performed from the perspective of a healthcare payer. It includes only direct healthcare costs associated with complications. The economic treatment costs for respective diabetes complications in 2009 were used in the modeling. For the purposes of indirect comparison, the data from the actual list of drugs covered by health insurance at time of modeling were used as drug costs (as of 1st October 2009 - the amount of drug reimbursement). The model took account of direct indicators of metabolic compensation - HbAlc change and body weight change.

The drug and intervention costs correspond with the costs registered by healthcare payers. 


\section{Therapeutic decision tree:}

We have used the pre-defined therapeutic approach applied in the CORE model [13]. The simulation baseline was defined as the switch from neutral protamine hagedorn insulin (long lasting insulin) to insulin detemir or insulin glargine in the treatment of DM.

Discounting: discount rate $5 \%$.

Patient cohort size: 1000 .

Simulation time threshold: 35 years.

We have determined a full cost analysis.

The model included:

direct indicators of metabolic compensation - glycated hemoglobin HbA1c change, weight change, incidence of hypoglycaemia

DM treatment cost in 2009

Quality of life identified within the cross-section research

\section{RESULTS AND DISCUSSION}

\section{Evaluation of DM pharmacotherapeutic direct costs}

According to the data from NCFHI, the number of diabetic patients increased by 147\% (1980 versus 2008: 122197 versus 302 361, respectively). The mean inter-annual growth was $3.7 \%$. During the same period, the prevalence increased from $2.4 \%$ to actual $5.6 \%$. The incidence was higher in women than in men (6.0\% and 5.0\%, respectively.) The prevalence of DM in the Slovak republic is higher if compared with other European countries. Most patients suffer DM2 and are in the fifth and sixth decennium (52\%) [14, $15]$.

The trends in consumption of antidiabetic medications indicate a relatively steady consumption of the number of packages (Table 1); however, the financial rise of antidiabetic medications and its growing trend is alarming (Table 2).

Table 1. Overview of consumption and costs of antidiabetics in the Slovak Republic

\begin{tabular}{|l|c|c|}
\hline Year & $\begin{array}{c}\text { Insulin } \\
\text { [packages] }\end{array}$ & $\begin{array}{c}\text { PAD } \\
\text { [packages] }\end{array}$ \\
\hline 2004 & 687915 & 1358213 \\
\hline 2005 & 724158 & 1453086 \\
\hline 2006 & 756561 & 1595093 \\
\hline 2007 & 760587 & 1729723 \\
\hline 2008 & 787478 & 1800471 \\
\hline 2009 & 825569 & 1850535 \\
\hline 2010 & 790384 & 1842237 \\
\hline
\end{tabular}


Table 2. Costs of insulin and non-insulin antidiabetics in the Slovak Republic

\begin{tabular}{|l|l|l|c|c|c|}
\hline Year & $\begin{array}{l}\text { Total costs } \\
\text { [euro] }\end{array}$ & $\begin{array}{l}\text { Insulin } \\
\text { [euro] }\end{array}$ & $\begin{array}{l}\text { \% of all } \\
\text { AD costs }\end{array}$ & $\begin{array}{l}\text { PAD } \\
\text { [euro] }\end{array}$ & $\begin{array}{l}\text { \% of all } \\
\text { AD costs }\end{array}$ \\
\hline 2004 & 23844416 & 14939661 & 62.65 & 8904755 & 37.35 \\
\hline 2005 & 27038350 & 17035663 & 63.01 & 10002687 & 36.99 \\
\hline 2006 & 30798228 & 19654783 & 63.82 & 11143445 & 36.80 \\
\hline 2007 & 33372365 & 21717990 & 65.08 & 11654375 & 34.92 \\
\hline 2008 & 38951247 & 25564777 & 65.63 & 13386470 & 34.37 \\
\hline 2009 & 38713649 & 22958314 & 59.3 & 15755335 & 40.70 \\
\hline 2010 & 39369628 & 22229153 & 56.46 & 17140475 & 43.54 \\
\hline
\end{tabular}

$\mathrm{AD}$ - antidiabetic treatment, PAD - peroral antidiabetics

When comparing the costs in recent years, the highest costs were reported in $2010-$ $€ 39369628$, i.e. approximately 15 million euro higher than the costs in 2005 . High annual increase in costs for antidiabetics was experienced in 2008, when about 5 million euro more was spent for antidiabetic treatment. On the other hand the overall costs for antidiabetic medications in 2009 decreased by approximately $€ 237598$. Proportionally the lowest costs for insulin medications, representing a value of €22 229153 were reported in 2010, which comprised over a half of the overall costs $(56.46 \%)$. Logically, the highest costs for peroral antidiabetics in recent years were reported in 2010, which comprised a value of $€ 17140475$ (43.54\%) of the overall drug costs for DM treatment.

Table 3. Structure of pharmacotherapy according to selected age groups

\begin{tabular}{|c|c|c|c|c|c|c|c|}
\hline $\begin{array}{c}\text { Age } \\
\text { (yrs) }\end{array}$ & $\mathbf{N}$ & $\begin{array}{c}\text { Insulins } \\
\text { €/patient }\end{array}$ & $\begin{array}{c}\text { PAD } \\
\text { €/patient }\end{array}$ & $\begin{array}{c}\text { Total } \\
\text { €/patient }\end{array}$ & $\begin{array}{c}\text { Non- } \\
\text { diabetic } \\
\text { drugs } \\
\text { €/patient }\end{array}$ & $\begin{array}{c}\text { Drugs } \\
\text { total } \\
\text { €/patient }\end{array}$ & $\begin{array}{l}\text { Diabeti } \\
\text { drugs } \\
\text { \%/patie }\end{array}$ \\
\hline $50-59$ & 3958 & 136.75 & 92.36 & 230.21 & 356.84 & 587.08 & 39.2 \\
\hline $60-69$ & 4123 & 119.99 & 89.97 & 210.72 & 466.83 & 677.56 & 31.1 \\
\hline $70-79$ & 2563 & 111.09 & 76.20 & 188.15 & 460.26 & 648.41 & 29 \\
\hline $80-89$ & 659 & 86.72 & 58.03 & 145.65 & 374.37 & 520.05 & 28 \\
\hline $90+$ & 30 & 71.88 & 53.65 & 125.56 & 326.56 & 452.12 & 27.8 \\
\hline
\end{tabular}

PAD - peroral antidiabetics 
Table 4. Health insurance costs per non-diabetic patient and diabetic patient in selected age groups

\begin{tabular}{|c|c|c|c|}
\hline $\begin{array}{c}\text { Age } \\
\text { (years) }\end{array}$ & $\begin{array}{c}\text { Non-diabetic pt. } \\
(\boldsymbol{\epsilon} / \text { year })\end{array}$ & $\begin{array}{c}\text { Diabetic pt. } \\
(\boldsymbol{€} / \text { year })\end{array}$ & $\begin{array}{c}\Delta=\text { diabetic - non-diabetic } \\
\text { (€/year) }\end{array}$ \\
\hline $50-59$ & 229.26 & 695.35 & 466.63 \\
\hline $60-69$ & 342.73 & 796.12 & 453.39 \\
\hline $70-79$ & 437.35 & 771.22 & 333.87 \\
\hline $80-89$ & 359.43 & 638.11 & 278.69 \\
\hline $90+$ & 224.10 & 476.89 & 252.79 \\
\hline Average & $\mathbf{2 9 2 . 9 9}$ & $\mathbf{7 4 5 . 7 8}$ & $\mathbf{4 5 2 . 7 9}$ \\
\hline
\end{tabular}

Overall direct drug costs for DM rank 4th after the treatment of hypertension, respiratory tract diseases, and oncological diseases [16].

Our results presented in Tables 3 and 4 demonstrate significantly higher costs of drug consumption in DM patients as compared to non-diabetic patients, expressed in €/year. The treatment of a patient with DM in the age group between 50 and 59 is three times more expensive as compared to a non-diabetic patient. On average, treatment of DM patients over 50 years of age is 2.5 times more expensive as compared to the treatment of non-diabetic patients.

\section{Disease-related quality of life}

From the medicine perspective, the quality of life follows the impact of the disease on an individual's physical or mental state, the way of life, and personal satisfaction [17].

The difference between overall life satisfaction (approximately 0.1212 points) between men and women was not statistically significant $(\mathrm{F}=0.58, \mathrm{t}=0.12, \mathrm{p}=0.990)$. Significant differences in overall life satisfaction were noted in research groups divided by type of diabetes and incidence of depression. When evaluating the significance in differences, the difference between patients with DM1 and DM2 is systematic and noncoincidental $(\mathrm{F}=0.985, \mathrm{t}=2.183, \mathrm{p}<0.001)$. The size of score differences is considered significant (Figure 1). The difference in scores reached by respondents with and without acute depression is considered equally significant $(\mathrm{F}=0.66, \mathrm{t}=2.163$, $\mathrm{p}<$ 0.001). The mean difference score between these groups was 20.1. Based on these differences, DM1 patients in general expressed more satisfaction with their quality of life as compared to DM2 patients. At the same time, based on the results, respondents with acute depression expressed less satisfaction with their quality of life as compared to respondents without depression.

When comparing the DM1 and DM2 patients, a significantly higher anxiousness score was reported in DM2 patients. This fact cannot be satisfactorily explained, as the comorbidity of diabetes mellitus and depression is a new topic only recently being addressed by experts [8]. 
Our results of the life satisfaction questionnaire apparently confirmed the presented hypothesis. Diabetes mellitus is a somatic disease affecting overall health status of an individual along with personal satisfaction with his/her health and physical condition. The results in the group indicate that the disease leads both to unfavorable health condition and deterioration of the financial situation. According to patients' statements, the costs associated with diabetic diet and treatments are financially demanding. Many respondents would mostly welcome being entitled to a higher number of Glucomer test strips, which would decrease their financial burden, thus contributing to better life satisfaction with their financial situation.

Resulting from the evaluation of the self-assessment rating scale, $48 \%$ of patients reported "actual depression." This result corresponds with the statement that the incidence of actual depression in diabetic population is 2 times higher as compared to healthy population [18]. When looking at the international studies, the data is comparable with the WHO study, despite having used a different methodology. We found that actual depression was higher and the increased incidence of depression in DM patients is not insignificant. Depression in DM1 is more a result of psychosocial consequences while depression associated with DM2 precedes the disease. The mean STAI X-2 score of a standardized group was significantly lower as compared to the score found in the investigated group, which is considered clinically significant.

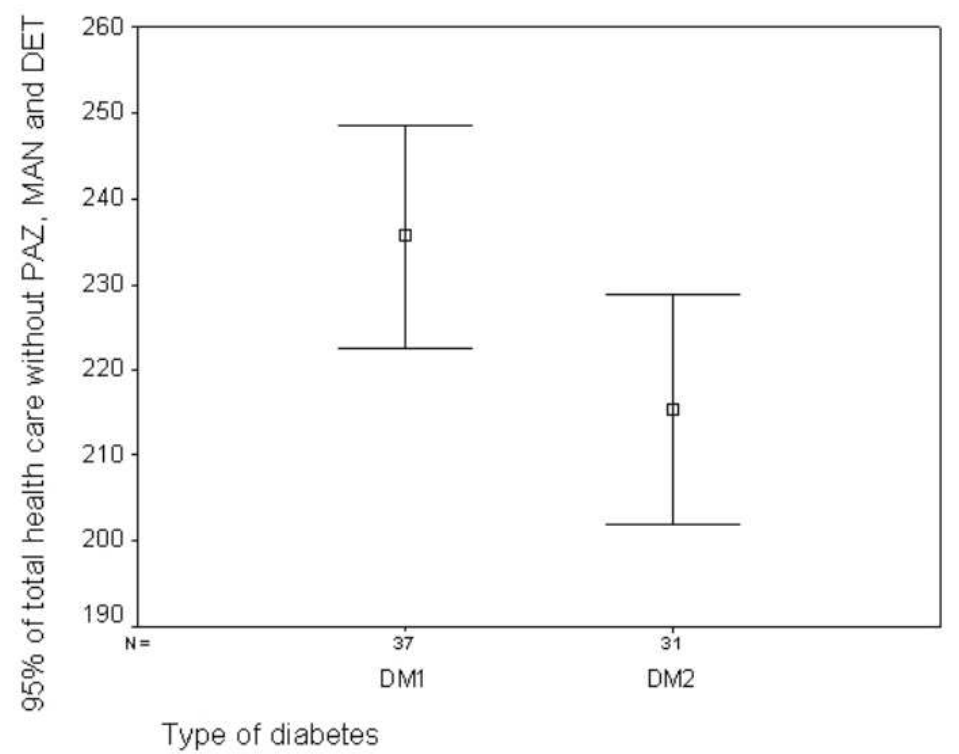

Figure 1. Comparison between overall life satisfaction score in DM1 patients and DM2 patients PAZ - work, MAN - international classification of diseases, DET - relationship to children

\section{Pharmacoeconomic model of DM treatment and complications}

With their pharmacokinetic and pharmacodynamic profiles, the assessed insulins detemir and glargine comply better with the physiological needs of an organism in substitution of basal secretion than classical human NPH insulins [19]. The clinical 
outcomes demonstrate that both of them are at least equally effective as NPH insulin administered in one or two daily doses, leading to the improvement of fasting and predinner glycemia control and the hypoglycemia risk is substantially lower than the risk associated with NPH insulin. Detemir, compared to glargine, statistically significantly decreases HbA1C. The difference is approximately $15 \%$ in favor of detemir. Detemir also statistically significantly decreases the risk of night hypoglycemia. The difference compared to glargine is about $19 \%$. However from the pharmacoeconomic point of view (Table 6) when using detemir the difference in direct costs in the time horizon 35 years is $€ 867$ by prolonging the life expectancy by 0.130 year. The cost items used (treatment of acute myocardial infarction and treatment of cerebrovascular accident) in the model are significantly lower when compared with some published papers.

Table 6. Comparison of pharmacoeconomic indicators detemir vs glargine (IMS Core model)

\begin{tabular}{|l|c|}
\hline Expected life expectancy & 0.130 \\
\hline QALE & 0.079 \\
\hline Direct costs $(€)$ & 867 \\
\hline Non-direct costs $(€)$ & -2 \\
\hline Combined costs $(€)$ & 864 \\
\hline Direct costs $(€) /$ expected life expectancy & 6643 \\
\hline Direct costs (€)/QALE & 10957 \\
\hline Non-direct costs (€)/expected life expectancy & -17 \\
\hline Non-direct costs $(€) /$ QALE & -29 \\
\hline Combined costs $(€) /$ expected life expectancy & 6625 \\
\hline Combined costs $(€) / Q A L E$ & 10928 \\
\hline
\end{tabular}

\section{CONCLUSION}

Resulting from the National Centre of Health Information statistical data, diabetes mellitus including DM complications is a serious health problem in the Slovak Republic: DM prevalence $(5.6 \%$, of which $5.1 \%$ is represented by men and $6.1 \%$ by women) is higher as compared to developed European countries. The highest number of DM patients was in the age group between 50 and $69(52 \%)$, and $90 \%$ of patients were diagnosed with Type 2 diabetes mellitus.

The annual costs for pharmacotherapy of diabetes mellitus in Slovakia range around $€ 30$ million. High costs are associated with insulin treatment of patients with DM1 and DM2. The insulin consumption expenditures are over $€ 20$ million, although the number of patients is two-fold lower as compared to patients treated with oral antidiabetics. The annual costs for oral antidiabetics in DM2 stand at $€ 10$ million, comprising a two-fold lower value as compared to the insulin costs.

The treatment of diabetes itself and its complications represents one part of care for diabetic patients. The quality of life assessment demonstrates discontent of DM patients with their health and financial situation. Apart from physical and mental problems, diabetes mellitus poses a financial burden on patients. Patient education provided by 
physicians and nurses, as well as by psychologists and psychiatrists would at least partially reduce the physical and mental impact of the disease. Despite the occurrence of severe mental diseases in diabetic patients this fact is being underestimated in practice. In addition to healthcare improvement attention should be paid to psychosocial problems and comorbidities of diabetes and mental diseases.

The cost analysis performed from the healthcare payer's perspective has demonstrated high direct healthcare costs for DM and DM complications. The result reflects the real effectiveness rate of evaluated medications.

\section{REFERENCES}

1. ETTARO, L. et al.: The economic burden of diabetes, Pharmaeconomics, 2004, 22, p. 149-164

2. DOLEŽAL, T. Farmakoekonomické aspekty liečby diabetu, Farmakoekoomika, 20063 , 1, p.8-12

3. GILMER, T. P. et al.: Predictors of health care costs in adults with diabetes, Diabetes care 2005,28 , p. 59-64

4. FOLTÁN, V. et al.: Lieky, lieková politika, farmakoekonomika, 1 vydanie, Propact, $2003186 \mathrm{~s}$

5. EISENBERG, J. M.: Clinical economics: a guide to the economic analysis of clinical practices, JAMA, 1989, 262 (20), p.2879-2886

6. LILJAS, B.: How to calculate indirect costs in economic evaluations, Pharmacoeconomics, 1997, 13, (1), s. 1-7

7. WORLD HEALTH ORGANIZATION. WHOQOL-BREF Introduction, Administration, Scoring and Generic Version of Assessment [online]. Geneva: The WHOQOL Group, 1997, p. 18 <www.who.int/entity/mental_health/media/en/76.pdf.> Assessed: 20.3.2006

8. DŽUKA, J. et al. Psychological dimension of quality of life. Prešov: Prešov University, 2004. 519 p.

9. ANDEL, M. et al.: A multinational, multicentre, observational, cross sectional survey assessing diabetes secondary care in Central and Eastern Europe (DEPAC SURVEY), Diabetic Medicine 2008, 25 (10), p. 25-31

10. TARRIDE JE - HOPKINS R - BLACKHOUSE G. et al. A review of methods used in long-term cost-effectiveness models of diabetes mellitus treatment. Pharmacoeconomics. 2010 Apr 1; 28(4), p. 255-77.

11. PALMER, A. J. et al.: The CORE diabetes model: Projecting long term clinical outcomes, costs and cost effectiveness of interventions in diabetes mellitus (types 1 and types 2) to support clinical and reimbursement decision-making, Curr Med Res Opin 2004, 20 (Supp11):S5-S26

12. UK PROSPECTIVE DIABETES STUDY (UKPDS) GROUP. Intensive blood-glucose control with sulfonylureas or insulin compared with conventional treatment and risk of complications in patients with type 2 diabetes (UKPDS 33), Lancet 1998, 352, p. 837853.

13. DRUMMOND M. F. - O BRIEN B. - STODDART G. L, - TORRANCE G. W.: Methods for the economic evaluation of health care programmes, Oxford University press, $2^{\text {nd }}$ edition, 2000, $305 \mathrm{p}$.

14. MASSI-BENEDETTI, M.: The Cost of Diabetes Type II in Europe. The CODE-2 Study. Diabetologia 2002, 45; S1-S4. 
15. ILAVSKA, A. - GLATZ, P. - HLOSKA, A. - FILKO, M. Economic evaluation of type 2 diabetes, impact of pricing and reimbursement reforms. In: Value in Health2010. 13, 3, p. A66.

16. KAMENSKÝ, G. Costs and benefits of preventive medication intervention in patients with high cardiovascular risk aged between 45 and 64 in Slovakia. Pharmacoeconomics and Drug Policy 2008, 4, 1, p. 11-17.

17. SHABAN, A.et al.: The prevalence of depression and anxiety in adults with type 1 diabetes, Diabetic Medicine 2006, 23, p. 445-448

18. HRACHOVINOVÁ, T.: Depression and diabetes mellitus: psychosocial factors Available at http://journal.diabetes.org/clinical diabetes/v16n21998/PG91.html> Assessed: 20.10 .2007

19. HEISE, T. -PIEBER, T. R.: Towards peakless reproducible and long acting insulins. an assessment of the basal analogues based on isoglycemic clamp studies., Diabetes Obes Metab 2007, 9 (3), p. 290-299

Registered, April 15, 2011

Accepted: May 20, 2011

\author{
Adriana Ilavská, MD., PhD \\ Medispektrum s.r.o, \\ Diabetologic and Metabolic Centre \\ Gercenova 4/A, \\ 85101 Bratislava \\ ilavska@medispektrum.com
}

\title{
Vzt'ah klinickej efektivity a farmakoekonomickej nákladovosti u pacientov s diabetes mellitus
}

\author{
${ }^{1}$ Ilavská A., ${ }^{2}$ Cviková V., ${ }^{3}$ Šimúnová E., ${ }^{4}$ Hroncová D., ${ }^{5}$ Foltán V. \\ ${ }^{1}$ Diabetologické a metabolické centrum, Medispektrum s.r.o, Bratislava, SR \\ ${ }^{2}$ Filozofická fakulta, Univerzita Komenského, Bratislava, SR \\ ${ }^{3}$ AT\&T Slovakia, Bratislava, SR \\ ${ }^{4}$ Mediforum, nezisková organizácia Bratislava, SR \\ ${ }^{5}$ Farmaceutická fakulta, Univerzita Komenského, Bratislava, SR
}

Diabetes mellitus a prediabetes sa stali celosvetovým zdravotným a sociálnym problémom pre neustále narastajúci výskyt ochorenia. Spôsob a efektivita liečby majú rozhodujúcu úlohu pri ovplyvňovaní poskytovaných nákladov zo systému zdravotnej starostlivosti, s významnými ekonomickými dôsledkami. Diabetes mellitus ekonomicky zat’ažuje až 15 \% rozpočtu na zdravotníctvo v Slovenskej republike.

Práca sa zameriava na hlavné okruhy ekonomického vplyvu diabetes mellitus na zdravotný systém: celkové odhady priamych nákladov na diabetes a jeho komplikácií; vplyv nákladov na starostlivost' a zdravotné výsledky; kvantifikovanie spotreby antidiabetík; posúdenie kvality života a farmakoekonomické modelovanie z pohl'adu platcu za zdravotnú starostlivost'. 
Práca sa zaoberá analýzou spotreby liekov a nákladov na lieky za obdobie $2004-2010$. Liečba inzulínom alebo perorálnymi antidiabetikami je na Slovensku dostupná pre všetkých pacientov v závislosti na stave ochorenia. Analýza nákladov jasne ukazuje, že diabetológia má vel'ký vplyv na celkové náklady na zdravotnú starostlivost'. Práca potvrdila, že diabetes mellitus je nákladné ochorenie, s predpokladom d'alšieho zvyšovania. Potreba ekonomických zist'ovaní bude aj nad’alej rást' vzhl'adom na zvyšujúci sa dopyt a obmedzené zdroje. Kontrolu nákladov možno dosiahnut' posilnením úlohy farmakoekonomiky v procesoch rozhodovania v Slovenskej republike.

Acta Facult. Pharm. Univ. Comenianae 58, 2011, p. 17 - 27. 